\title{
CELAH HUKUM TERJADINYA PRAKTIK PERKAWINAN DI BAWAH UMUR DAN TINDAKAN KONDUSIF PERLINDUNGAN HAM
}

\author{
Yayuk Kusumawati \\ Institut Agama Islam (IAI) Muhammadiyah Bima \\ Jl. Anggrek No. 16 Ranggo Na'e Kota Bima \\ yayukalkhansa@gmail.com
}

\section{Abstract:}

Perkawinan merupakan perbuatan yang sakral untuk dilakukan dengan tujuan untuk menciptakan keluarga yang sakinah. Hal ini dianjurkan dalam agama Islam agar melangsungkan perkawinan jika dianggap mampu, lebih lanjutnya pemerintah pun mengatur dengan rapi tentang usia perkawinan sebagaimana yang berbunyi dalam Undang-Undang Nomor 1 Tahun 1974 tentang Perkawinan pada Pasal 7 ayat (1) bahwa usia perkawinan bagi laki-laki harus mencapai 19 tahun dan perempuan harus berumur 16 tahun hal tersebut dianggap mampu untuk melakukan perkawinan. Faktanya bahwa masih ada yang melanggar peraturan tersebut dan melangsungkan perkawinan dengan meminta dispensasi nikah ke pengadilan yaitu di usia yang disebut Anak. Selain itu juga legalitas dari hukum adat yang tidak memiliki batasan usia perkawinan, artinya produk hukum yang masih goyah dan lemah akibat inkonsistensi hukum menimbulkan celah bagi pelaku perkawinan di bawah umur. Anak yang seharusnya dilindungi, dibimbing dan masa untuk bermain dengan teman sebayanya harus berperan sebagai orang dewasa dengan melakukan perkawinan dibawah umur. Dampaknya tidak bisa dielakkan yaitu putus sekolah, kekerasan dalam rumah 
tangga, perceraian dan lain sebagainya. Untuk itu perlu tindakan kondusif dari aspek HAM, peran dan fungsi HAM untuk melindungi hak anak harus diintensifkan agar anak bisa dijaga sebagai aset bangsa dan Negara.

\section{Keywords: Celah Hukum, Perkawinan di bawah Umur, Perlindungan HAM}

\section{Pendahuluan}

Perkawinan memang fitrah manusia untuk hidup saling berpasangan. Dalam sejarah kenabian ada salah satu Istri Nabi Muhammad yaitu Aisyah yang dinikahinya pada usia 6 tahun digauli pada saat balig akan tetapi ini bukan berarti kita jadikan sebuah hujah bahwa dibolehkan anak di bawah umur untuk menikah. Secara eksplisit beda kondisi, beda mental dan wawasan keilmuan. Permasalahannya generasi sekarang apalagi anak di bawah umur hanya berdasarkan perasaan suka saja, dengan cara bergaul yang tidak sesuai syariah terjadi hal yang tidak diinginkan dan kemudian jalan satu-satunya perspektif mereka adalah melakukan perkawinan. Sehingga terjadilah celah hukum untuk mencari jalan agar mensahkan perbuatan tersebut, walaupun dalam hal ini pemerintah telah membuat batasan umur perkawinan sebagaimana tercantum dalam UU Nomor 1 Tahun 1974 pasal 7 ayat 1 yang berbunyi "Perkawinan hanya diizinkan jika pihak pria sudah mencapai umur 19 (sembilan belas) tahun dan pihak wanita sudah mencapai umur 16 (enam belas) tahun ", harapannya adalah ketika menikah tidak cukup umur maka akan berakibat pada rumah tangga yang dibangun menjadi retak hanya karena persoalan ekonomi, mental belum siap dan lain sebagainya, melanjutkan dari Pasal di atas justru di pasal 7 ayat 2 menimbulkan inkonsistensi produk hukum sebagaimana berbunyi "Dalam hal penyimpangan terhadap ayat (1) pasal ini dapat meminta dispensasi kepada Pengadilan atau Pejabat lain yang ditunjuk oleh kedua orang tua pihak pria 
maupun pihak wanita" artinya pasal 7 ayat 1 di atas menjadi tumbang dan lemah ketika dihadapkan dengan pasal 7 ayat 2 dan akan dijadikan sebuah celah hukum yang bisa melegalkan dan mensahkan perkawinan.

Undang-undang perkawinan yang dianggap sebagai perlindungan bagi anak menimbulkan inkonsisten, maka hal yang terjadi tidak mampu dicegah dan akan terus berulang-ulang sebagaimana halnya data yang dikeluarkan oleh Menko PMK pada tahun 2018 bahwa "NTB termasuk paling tinggi kedua setelah gorontalo yang melakukan perkawinan dibawah umur sekitar 4,5\%"1. Hal ini bisa terjadi karena sebuah pola perilaku yang menyimpang dalam kehidupan sosial, harapan anak yang seharusnya kelak menjadi aset bangsa yang berharga justru menjadi boomerang untuk Negara sendiri akibat pergaulan yang bebas maka hal yang tidak diharapkan terjadi yaitu perkawinan yang semestinya usia anak memiliki batas faktanya usia tersebut secara pikiran, mental belum begitu matang ketika dipaksa untuk berperan sebagai orang dewasa dengan masalah yang lebih besar yaitu perkawinan dibawah umur. Hukum perkawinan dari segi hukum positif hal ini boleh dilakukan jika ada yang namanya dispensasi nikah yang diberikan oleh pejabat yang berwenang sebagaimana yang tertuang dalam pasal 7 ayat 2 UU No. 1 Tahun 1974 terkait dispensasi nikah.

Disisi lain pada tataran HAM bahwa perkawinan dibawah umur telah melanggar hak tumbuh kembang anak, hak pendidikan dan lain sebagainya, anak yang pada hakikatnya harus dilindungi, diayomi dan dibimbing karena mereka adalah bagian dari kelompok rentan sebagaimana yang berbunyi bahwa setiap orang yang termasuk kelompok masyarakat yang rentan berhak memperoleh perlakuan dan perlindungan lebih berkenaan

${ }^{1}$ Www.detikntb.com

Sangaji Jurnal Pemikiran Syariah dan Hukum 
dengan kekhususannya. Dalam penjelasan pasal tersebut yang dimaksud dengan kaum rentan adalah anak-anak, orang lanjut usia, fakir miskin, wanita hamil dan penyandang cacat2. Maka tindakan preventif dan solutif dari segi Hak Asasi Manusia menjadi indikator yang sangat penting karena hal ini berkaitan dengan keadaan anak, sejauhmana HAM mampu memberikan perlindungan agarpraktek perkawainan dibawah umur yang marak terjadi sampai sekarang bisa ditekan, terlepas dari peran orang tua, lingkungan sosial, sekolah dan stackeholder lainnya,sebagaimana halnya tercantum dalam undang-undang tentang HAM yaitu perlindungan, pemajuan, penegakan dan pemenuhan Hak Asasi Manusia merupakan tanggung jawab pemerintah disamping juga masyarakat ${ }^{3}$. Perlu ada regulasi yang kuat dan produk hukum yang konsisten agar tidak memiliki dalih untuk mencari celah pembenaran perkawinan di bawah umur yang akhirnya bisa menjadi budaya dan menekan pertumbuhan anak, stakeholder yang dianggap mampu untuk berperan menjaga anak bangsa karena pada hakekatnya tujuan perkawinan adalah membentuk keluarga yang bahagia dan kekal berdasarkan Ketuhanan Yang Maha Esa ${ }^{4}$, sebagaimana yang diamanatkan dalam undang-undang perkawinan.

\section{Pengertian Anak dan Perkawinan di Bawah Umur}

Berbagai definisi batasan anak dapat ditemukan dalam beberapa peraturan perundangan yang berlaku di Indonesia, terdapat berbagai pengertian tentang anak namun pada prinsipnya keragaman batasan tersebut mempunyai implikasi dan tujuan yang sama yaitu memberikan perlindungan pada

\footnotetext{
2Pasal 5 ayat (3) Undang-undang No.39 Tahun 1999 tentang Hak Asasi Manusia

3Idem pasal 8

${ }^{4}$ Undang-undang perkawinan di Indonesia no.1 tahun 1974, Surabaya : arkola pasal 1
} 
anak. Anak adalah seseorang yang belum berusia 18 tahun termasuk anak dalam kandungan ${ }^{5}$. Selain itu juga terdapat pengertian lain tentang anak dalam undang-undang tentang HAM berbunyi anak adalah setiap manusia yang berusia di bawah 18 tahun dan belum menikah termasuk anak yang masih dalam kandungan apabila hal tersebut demi kepentingannya ${ }^{6}$. Sedangkan dalam undang-undang perkawinan jika ingin melakukan perkawinan maka usia laki-laki harus mencapai 19 tahun ke atas dan perempuan 16 tahun ke atas artinya jika usia perkawinan dilakukan di bawah standar yang telah ditentukan oleh aturan tersebut maka dianggap sebagai anak. Hampir sama dengan definisi sebelumnya dalam undang-undang yang berbeda bahwa sudah dinyatakan dengan jelas dan tegas bahwa batasan usia anak sebagaimana tercantum pada definisi di atas.

\section{Dwi Hukum (Positif dan Adat) Legalitas Perkawinan dibawah umur}

Perkawinan dibawah umur adalah perkawinan yang dilakukan dibawah usia yang disediakan serta disiapkan untuk dewasa yang diperbarui dan perbaikan rumah tangga ${ }^{7}$.yang dimaksud dalam hal ini adalah anak yang tidak sesuai batas perkawinan yaitu laki-laki harus berusia 19 tahun dan perempuan berusia 16 tahun, jika perkawinan terjadi dibawah usia batas yang telah menjadi peraturan maka perkawinan tersebut disebut sebagai perkawinan dibawah umur.

${ }^{5}$ Pasal 1 ayat (1) Undang-undang No 23 tahun 2002 tentang perlindungan anak

6 Pasal 1 ayat (5) Undang-undang No 39 tahun 1999 tentang HAM

${ }^{7 N u k m a n, 2009 . Y a n g ~ d i m a k s u d ~ d e n g a n ~ p e r n i k a h a n ~ d i n i . y o g y a k a r t a ~: ~}$ paradigma hal 32

Sangaji Jurnal Pemikiran Syariah dan Hukum 


\section{Aspek Sosial Perkawinan dibawah Umur}

Perkawinan merupakan bentuk tindakan sosial budaya, sedikit menyangkut kedudukan sosial yang bersangkutan ${ }^{8}$. Pada umumnya perkawinan berlangsung antara orang-orang yang mempunyai kedudukan sosial yang sederajat. Terkadang perkawinan tersebut menaikkan derajat seseorang atau bahkan menurunkan derajat mereka. Keadaan semacam itu terutama tampak pada masyarakat yang sistem stratifikasi sosialnya bersifat tertutup. Penjelasan tersebut tidak terlepas dari orientasi pemikiran tentang fungsi perkawinan bagi masyarakat Indonesia yang menganggap bahwa perkawinan sebagai suatu sistem sosial budaya yang dapat mengangkat status keluarga di tengah-tengah masyarakat. Prinsip seperti ini masih cukup besar pengaruhnya, sehingga orang-orang yang stratifikasi ekonominya dan pendidikannya rendah, semakin cenderung mendorong putra putrinya melangsungkan perkawinan di bawah umur.

Pemikiran masyarakat telah mengakui kehadiran perkawinan dibawah umur tersebut tidak membuat tercengang dalam lingkup masyarakat walaupun di era teknologi sekarang ini artinya, sebelum terjadinya perubahan teknologi terlebih dahulu telah terjadi perubahan gagasan baru dalam pola pikir ${ }^{9}$. Gagasan baru tidak terpengaruh dengan minimnya perkawinan di bawah umur justru hal ini tidak dianggap tabu sehingga pergaulan bebas terjadi karena usaha menfilter diri tidak ada, keluarga, lingkungan sosial yang terutama. Di era sekarang ini justru anak dipaksakan untuk dewasa, tingkah laku,pola pikir dan lain sebagainya akhirnya tindakan apapun berada di luar jalur kesanggupannya. hal ini tidak bisa dipungkiri bahwa

${ }^{8}$ Anshary, M. 2010. Hukum Perkawinan di Indonesia (Masalah-masalah Krusial). Yogyakarta: Pustaka Pelajar hlm 277-278

${ }^{9}$ Maspupah, Ade. 2014. People's Perseption About Early Marriage (A Case Study In Desa Sungai Kuning Kecamatan Singingi Kabupaten Kuantan Singingi). Jom FISIP Volume 1 No( 2), 1 - 15. 
perkawinan dibawah umur banyak yang melatar belakangi oleh beberapa faktor, seperti faktor ekonomi, pendidikan, sosial budaya, dan lingkungan. Faktor-faktor tersebut merupakan sebab yang dapat mendorong terjadinya perkawinan di bawah umur, bahkan karena faktor lemahnya ekonomi dan sosial budaya merupakan yang sangat dominan, suatu kenyataan dalam masyarakat bahwa anak yang putus sekolah disebabkan tidak adanya biaya, sehingga jika seorang anak putus sekolah maka peluang dan dorongan cepat kawin semakin kuat ${ }^{10}$.

Padahal perkawinan yang ideal untuk perempuan adalah 21-25 tahun sementara laki-laki 25-28 tahun karena di usia itu organ reproduksi perempuan secara psikologis sudah berkembang dengan baik dan kuat serta siap untuk melahirkan keturunan secara fisik pun mulai matang ${ }^{11}$, begitupun dengan kondisi laki-laki baik secara psikis emosional, ekonomi dan sosial. Melakukan perkawinan tanpa kesiapan dan pertimbangan yang matang dari satu sisi dapat mengindikasikan sikap tidak apresiatif terhadap makna perkawinan, sebagian masyarakat yang melangsungkan perkawinan di bawah umur ini dipengaruhi karena adanya berbagai macam faktor yang mendorong mereka untuk melangsungkan perkawinan dibawah umur $^{12}$. Melalui keadaan seperti itu secara aspek sosial perkawinan dibawah umur setidaknya menjadi suatu hal yang tabuh dimasyarakat agar orang tua maupun anak tidak menjadikan alasan pembenaran untuk melakukannya, dengan begitu untuk melakukan pergaulan yang negatif maupun perkawinan yang dilakukan antar kerelaan masing-masing

${ }^{10}$ Hanif, Yusuf. 2011. Kontroversi Perkawinan Anak dibawah Umur (Child Marriage).Bandung: CV. Mandar Maju hlm 71

${ }^{11}$ Kumalasari, Intan dan Andhyantoro, Iwan.2012. Kesehatan Reproduksi untuk Mahasiswa Kebidanan dan Keperawatan.Jakarta: Salemba Medika. Hlm 82

${ }^{12}$ Mohammad, M. Dlori. (2005) Jeratan nikah dini, wabah pergaulan. Yogjakarta: Binar Press.hlm 55

Sangaji Jurnal Pemikiran Syariah dan Hukum 
individu ataupun keluarga bisa difilter kejadiannya. Hal ini semacam Punishmen sosial yang diberikan agar sadar dengan tindakan tersebut, akan tetapi keseimbangan dasolen dan dasein inilah yang menjadi kenyataan bahwa keadaan sosial perkawinan dibawah umur menjadi hal biasa seperti di Lombok yaitu daerah yang terkenal dengan istilah merariq kodeq.

\section{Legalitas Perkawinan Di Bawah Umur Melalui Dispensasi Nikah}

Perkawinan adalah suatu hal yang fitrah terjadi dengan harapan akan membangun keluarga yang sakinah, mawaddah, warahmah kekuatan membangun keluarga impian tersebut dilihat lagi dari segi umur yang menjadi acuannnya sebagaimana disebutkan dalam Undang-Undang Perkawinan (UUP) Nomor 1 Tahun 1974 bahwa perkawinan hanya diizinkan jika pihak pria telah mencapai umur 19 tahun dan pihak wanita sudah berusia 16 tahun. Penyimpangan terhadap ketentuan usia kawin ini dapat dimintakan dispensasi kepada pengadilan atau pejabat lain yang ditunjuk oleh kedua orang tua pihak pria maupun pihak wanita. Dalam hal penyimpangan dalam ayat (1) pasal 7 ini dapat diminta dispensasi kepada pengadilan atau pejabat lain yang diminta oleh kedua orang tua pihak pria atau pihak wanita (pasal 7 (2) UU Perkawinan No. 1 Tahun 1974) ${ }^{13}$.

Pelaksanaan undang-undang perkawinan khususnya bagi masyarakat yang beragama Islam oleh Menteri Agama diterbitkan Peraturan Menteri Agama Nomor 3 Tahun 1975 mengenai kewajiban pencatat nikah dan tata kerja pengadilan agama dalam melaksanakan peraturan perundang-undangan perkawinan bagi mereka yang menganut agama Islam. Terdapat dalam Peraturan Menteri Agama antara lain diatur tentang prosedur untuk mengajukan dispensasi kepada pengadilan

13Pasal 7 ayat (1),ayat (2) Undang-undang No. 1 Tahun 1974 
agama sebagaimana berbunyi "Dispensasi pengadilan agama ialah penetapan yang berupa izin untuk calon suami belum mncapai umur 19 tahun dan atau calon istri belum mencapai umur 16 tahun yang dikeluarkan oleh pengadilan agama ${ }^{14 "}$

Dipertegas lagi dengan pasal lainnya yang berbunyi "Apabila seorang calon suami belum mencapai umur 19 tahun dan calon istri belum mencapai umur 16 tahun hendak melangsungkan perkawinan harus mendapat dispensasi dari pengadilan agama ${ }^{15}$ ".Maksudnya, diajukan oleh kedua orang tua pria maupun wanita kepada pengadilan agama dimana tempat tinggalnya ${ }^{16}$. Setelah pengadilan agama memeriksa dalam persidangan dan berkeyakinan, bahwa terdapat hal-hal yang memungkinkan untuk memberikan dispensasi, hal ini dilakukan agar pencatat perkawinan ada melalui jalur yang sesuai dengan ketentuan peraturan yang ada, oleh karenanya pemerintah melalui sebuah kebijakan dan peraturan memberikan dispensasi kepada kedua belah pihak untuk mendukung aktifitasnya dan juga agar terkabulnya perkawinan tersebut.

Surat dispensasi kawin dari pengadilan bagi mereka yang berada dibawah umur merupakan Sesuatu yang wajib ada dalam hal pemeriksaan berkas-berkas oleh PPN atau pembantu PPN setelah ada pemberitahuan untuk melaksanakan perkawinan. Dalam pasal 6 ayat 1 PP No. 9 tahun 1975 "pegawai pencatat yang menerima pemberitahuan kehendak melangsungkan perkawinan, meneliti apakah syarat-syarat perkawinan telah dipenuhi dan apakah tidak terdapat halangan perkawinan menurut undang-undang".

Berdasarkan pada pasal tersebut di atas dapatlah dianalisa terhadap suatu kebijakan dispensasi, sehingga dapatlah disimpulkan bahwa perkawinan pada semua tingkat umur tetap

${ }^{14}$ pasal 1 ayat 2 sub g Permenag Nomor 3 Tahun 1975 tentang kewajiban pencatat nikah

${ }^{15}$ Idem Pasal 13 ayat 1

${ }^{16}$ Idem Pasal 13 ayat 2

Sangaji Jurnal Pemikiran Syariah dan Hukum 
memiliki peluang untuk terjadinya berbagai resiko. Namun pada umur dewasa, orang dianggap lebih mampu untuk menggunakan nalar dalam menghadapi problematika keluarga. Lain halnya kalau di bawah umur, secara psikologis manusia dianggap lebih mudah bersifat kekanak-kanakan yang nantinya akan mempengaruhi kehidupan rumah tangganya. Sebaliknya yang dipahami bahwa perkawinan bukanlah untuk tujuan produksi semata, melainkan perkawinan sebagai sesuatu yang memerlukan tanggung jawab secara lahiriah dan batiniah.

Kompilasi Hukum Islam (KHI), yang disebarluaskan melalui Inpres Nomor 1 Tahun 1991, memuat perihal yang kurang lebih sama. Kompilasi Hukum Islam menyebutkan bahwa Batas usia perkawinan sama seperti pasal 7 Undang-undang No.1 Tahun 1974, namun dengan tambahan alasan "untuk kemaslahatan keluarga dan rumah tangga17". Untuk kemaslahatan keluarga dan rumah tangga, perkawinan hanya boleh dilakukan calon mempelai yang telah mencapai umur yang ditetapkan dalam, yakni calon suami sekurang-kurangnya berumur 19 tahun dan calon istri sekurang-kurangnya berumur 16 tahun ${ }^{18}$, dengan dalih kemaslahatan keluarga dan rumah tangga menjadi acuan diijinkannya perkawinan di bawah umur, perlu ditelaah lebih dalam lagi makna pasal tersebut agar makna kemaslahatan bukan dalam bentuk suatu solutif untuk anak yang dengan sengaja dinikahkan dengan kehendak oleh kedua orang tuanya atau bahkan nikah karena akibat dari pergaulan bebas.

Dilanjutkan lagi dalam aturan lainya yaitu bagi calon mempelai yang belum berumur 21 tahun harus mendapatkan izin sebagaimana yang diatur dalam pasal 6 ayat (2), (3), (4), dan (5) UU No.1 Tahun 1974. Maka, secara eksplisit tidak tercantum jelas larangan untuk menikah di bawah umur. Penyimpangan

17Pasal 1 Undang-undang Republik Indonesia Nomor 1 tahun 1974 tentang Perkawinan dan Kompilasi Hukum Islam. 2014. Jakarta: Grahamedia Press ${ }^{18}$ Idem pasal 7 ayat (1) 
terhadapnya dapat dimungkinkan dengan adanya izin dari pengadilan atau pejabat yang berkompeten. Terlebih dengan adanya institusi dispensasi nikah, peluang bagi terjadinya perkawinan di bawah umur 16 tahun menjadi sangat potensial. Artinya lemahnya aturan yang diterapkan dalam masyarakat bahkan antara pasal yang satu dengan yang lainnya inkonsistensi seperti pasal 7 ayat (1) dan ayat (2) di awal pembahasan pasal begitu rapi dan memberikan pemahaman terkait dengan perkawinan, akan tetapi berhadapan dengan pasal 7 ayat (2) menjadi dasar bagi yang melakukan perkawinan di bawah umur dengan jalan yang diijinkan tanpa hambatan hanya saja butuh prosedur-prosedur tertentu saja.

Dalam implementasinya, institusi ini sering digunakan untuk mencegah hubungan di luar perkawinan yang terjadi antara pasangan muda-mudi. Lazimnya kekhawatiran berasal dari orang tua yang tidak ingin melihat anak perempuannya hamil di luar nikah. Ketidakseimbangan konsep dalam bentuk aturan dengan pola tingkah laku masyarakat, lemahnya aturan yang dibuat semua menjadi kabur dan perkawinan di bawah umur tidak mampu dicegah sampai saat sekarang, walaupun secara eksplisit semua peraturan perundang-undangan yang membahas tentang perkawinan memiliki dasar yang sama tentang perijinan perkawinan di bawah umur karena pasal perpasal memiliki kaitanya antara yang satu dengan yang lain sebagai bentuk delegasi kewenangan dari Undang-Undang Perkawinan No 1 Tahun 1974.

\section{Legalitas Hukum Adat terhadap Perkawinan Di Bawah Umur}

Hukum adat di Indonesia menjadi salah satu kekuatan konstitusi yang berlaku di samping Undang-undang Dasar 1945 artinya Negara kita mengadopsi dwi hukum sebagai sumber hukumnya, karena sifat heterogen suku, budaya dan lainnya maka pemerintah mengijinkan adat masing-masing untuk 
mengatur dan mengontrol masyarakatnya sebagai mana yang berbunyi "Negara mengakui dan menghormati kesatuan-keatuan masyarakat hukum adat beserta hak-hak tradisionalnya sepanjang masih kidup dan sesuai dengan perkembangan masyarakat dan prinsip Negara Kesatuan Republik Indonesia, yang diatur dalam undang-undang 19 " artinya kehadiran hukum adat dan hukum positif berjalan beriringan serta berdampingan untuk kemakmuran bersama dalam menciptakan masyarakat yang damai.

Dalam masyarakat adat semua telah diatur dengan baik dan jelas salah satunya tentang perkawinan, salah satu contoh hukum adat yang terjadi di NTB Lombok suku Sasak yaitu (merariq kodeq) kawin dari usia dini menjadi hal yang biasa dilaksanakan asalkan mendapat persetujuan dari kedua calon mempelai perempuan. Inilah salah satu doktrin normatif yang terkandung dalam praktek merarigkodeq adalah rasa bangga terhadap identitas individu dan identitas keluarga pihak perempuan yang ditandai dengan adanya keinginan agar anak wanita yang dinikahi lelaki harus didahului oleh proses pelarian ${ }^{20}$. Kebanggaan tersebut memiliki kontribusi sosial bagi eksistensi keluarga di tengah komunitas masyarakat setempat. Terlepas, apakah pelarian akan berakhir dengan pernikahan atau tidak, yang jadi proses pelarian itu sendiri sudah merupakan tahapan penting yang cukup monumental dalam tata urutan prosesi pernikahan.

Kebanggaan sosial kultural inilah yang kemudian mampu memunculkan image dan legitimasi sosial bahwa pelarian sama sekali bukan suatu tindakan kriminal dalam tradisi Sasak. Padahal dalam hukum nasional ada ketentuan bahwa melarikan anak orang lain termasuk dalam kategori kriminal besar yang berada dalam rumpun pidana penculikan dan pemaksaan kehendak seseorang kepada pihak lain serta penghilangan

19 Pasal 18B ayat (2) Undang-undang dasar 1945

${ }^{20}$ Sulkhad, Kaharuddin. 2013. Merarik pada Masyarakat Sasak. Yogyakarta: Ombak. Hlm 50 
kemerdekaan yang harus dimiliki warga Negara ${ }^{21}$. Akan tetapi sekali lagi bahwa hukum positif menghargai kehadiran hukum adat selama hal itu tidak bertentangan dengan norma yang dijalani oleh mereka hal ini sebagai bentuk keseimbangan hukum.

Oleh karena itu cita hukum nasional menghargai eksistensi hukum yang secara horizontal terpraktekkan di tengah masyarakat. Proses perumusan hukum nasional juga menerima asumsi bahwa hukum mempunyai kekuatan berlaku jika diterima dan diakui oleh masyarakat. Konsep ini disebut dengan teori pengakuan ${ }^{22}$. Dalam konteks ini, tampak bahwa kawin lari usia dini cukup diterima di tengah publik Sasak, meski belum diketahui secara jelas presentasi keberpihakan masyarakat terhadap merariqkodeq. Bahwa dengan masih eksisnya perkawinan dibawah umur di era modern ini menjadi penguat argumentasi bahwa pengakuan oleh masyarakat merupakan suatu kenyataan bahwa hukum yang tak terelakkan.

Karena kenyataan yang terjadi hukum positif tidak mampu untuk mengatur pola kehidupan masyarakat maka perlu adanya keseimbangan dari hukum adat:

a. Hukum tidak tertulis pasti ada karena hukum tertulis tidak akan mungkin mengatur semua kebutuhan masyarakat yang perlu diatur dengan hukum.

b. Pada masyarakat yang sedang mengalami perubahan sosial yang cepat.

${ }^{21}$ KUHPer (Kitab Undang-undang Hukum Perdata), KUHP (Kitab Undangundang Hukum Pidana), KUHAP (Kitab Undang-undang Hukum Acara Pidana). 2008. Yogyakarta : Pustaka Yustisia. Pasal ...???

${ }^{22}$ Yasin, Nur. 2008. Hukum Perkawinan Islam Sasak.Yogyakarta: UINMalang Press hlm 175

Sangaji Jurnal Pemikiran Syariah dan Hukum 
c. Peranan hukum tidak tertulis lebih menonjol dari hukum tertulis ${ }^{23}$.

\section{Akibat Hukum Perkawinan di Bawah Umur}

Perkawinan di bawah umur yang dilakukan tidak bisa dipungkiri setiap keputusan yang diambil akan memiliki konsekuensi hukum, secara suka ataupun tidak suka akan dialami oleh mereka yang melakukan hal tersebut antara lain :

a. Putus Sekolah

Hampir tidak bisa dipastikan pengantik anak adalah generasi putus sekolah dan bahkan yang tidak mengenyam pendidikan sama sekali, kesempatan mereka untuk mengenyam pendidikan yang lebih tinggi menjadi mimpi bahkan tidak sedikit pula yang tidak menyelesaikan bangku pendidikan dasar ${ }^{24}$.

b. Kekerasan dalam rumah tangga

Yang menjadi korban KDRT biasanya gadis muda ayang dikawinkan di usia dini lazimnya bersuamikan pria yang berusia jauh lebih tua dari dirinya, akibat margin usia yang jauh inilah hamper muncul problem komuikasi keluarga, ekonomi maupun seksual diantara keduannya sehingga muncullah kekerasan dalam rumah tangga tersebut yang bisa menyakitkan pasangan dan yang menjadi korbannya adalah perempuan sebagai kaum rentan ${ }^{25}$.

23Purba, Rehngena. 2006. Hukum Adat dalam Yurisprudensi, Majalah Hukum Nasional No. 2. ISSN 0216 - 0227, BPHN, Departemen Hukum dan HAM RI. Hlm 30

${ }^{24}$ Gultom, Maidin. 2013. Perlindungan Hukum terhadap Anak dan Perempuan.Bandung: PT. Refika Aditama hlm 100.

${ }^{25}$ Khaeron Sirin.2009. Fikih Perkawinan dibawah Umur. Jakarta: Ghalia Indonesia hlm 33 
c. Perceraian

Akibat tidak harmonisnya rumah tangga, maupun komunikasi yang tidak sejalan dengan kondisi rumah tangga perkawinan dibawah umur bisa berdampak pada terjadinya perceraian, hal ini tidak bisa dielakkan perempuan yang menjadi korban sulit dan bahkan tidak bisa melanjutkan sekolah bahkan malu untuk melanjutkan sekolah, status janda di usia muda pun menjadi identitas tersendiri. Perkawinan di bawah umur tidak jarang memunculkan banyak masalah yang sangat pelik di dalam rumah tangga dan kerap berakhir dengan perceraian ${ }^{26}$.

\section{Tindakan Kondusif Perlindungan HAM Terhadap Anak Perkawinan Di Bawah Umur}

Kerentanan anak-anak terhadap pelanggaran HAM adalah sebagai akibat manusia yang "lemah".Usia dan faktor kematangan psikologis dan mental membuatnya kerap kali terpinggirkan dalam pengambilan kebijakan. Dalam convetion on the Rights of the Child, terdapat empat butir pengakuan masyarakat internasional atas hak-hak yang dimiliki oleh kaum anak, yakni :

a. Hak terhadap kelangsungan hidup anak (survival rights);

b. Hak terhadap perlindungan (protection rights);

c. Hak untuk tumbuh dan berkembang (development rights);

d. Hak untuk berpartisipasi (participation rights) ${ }^{27}$

Selain hak di atas pemerintah juga memberikan perlindungan pada aspek pendidikan bagi anak-anak yang

${ }^{26}$ Wiliam. J. Goode. 1985. Sosiologi Hukum. Alih bahasa Hanoun Hasyim.Jakarta : Diaksara.

HIm 110

${ }^{27}$ Erwin, Muhammad. 2013.Pendidikan Kewarganegaraan republic Indonesia. Bandung : PT refika aditama hlm 174

Sangaji Jurnal Pemikiran Syariah dan Hukum 
kurang mampu, anak terlantar dan anak yang bertempat tinggal di daerah terpencil pemerintah bertanggung jawab untuk memberikan biaya pendidikan dan bantuan secara cuma-cuma atau pelayanan khusus dan mendorong masyarakat untuk berperan secara aktif untuk itu ${ }^{28}$. Untuk memperkuat perlindungan anak Indonesia juga sudah memiliki UU Nomor 23 Tahun 2002 tentang perlindungan anak. Pasal 1 angka (2) menyatakan dengan tegas bahwa perlindungan anak dan hakhaknya agar dapat hidup, tumbuh, berkembang dan mendapat perlindungan dari kekerasan dan diskriminasi.

Begitu pun dalam pengaturan HAM internasional seperti halnya Deklarasi Universal HAM tidak membatasi umur usia kawin seseorang. Namun, secara tersurat dalam konvensi Hak Anak pada pasal 1 yang menyebutkn bahwa "Yang dimaksud anak dalam konvensi ini adalah setiap manusia yang berusia di bawah delapan belas tahun, kecuali berdasarkan undang-undang yang berlaku bagi anak-anak ditentukan bahwa usia dewasa dicapai lebih awal" diberikannya wewenang bagi setiap Negara dalam pembatasan umur ini membuat Indonesia merefisi ulang usia perkawinan bagi perempuan dengan mempertimbangkan kondisi kultur dan budayanya. Berkenaan dengan ketentuan ini dapat diambil kesimpulan juga bahwa Indonesia menerapkan batas usia kawin 16 tahun untuk perempuan dan 19 tahun untuk laki-laki.

Bunyi pasal 61 undang-undang tentang HAM Bahwa setiap anak berhak untuk beristirahat, bergaul dengan anak yang sebaya, bermain, berkreasi sesuai dengan minat, bakat, dan tingkat kecerdasannya demi pengembangan dirinya. Hal ini menyebutkan bahwasannya ketika dalam usia anak, anak masih diberi hak untuk memperoleh kebebasan dan berkreasi sesuai dengan mengeksploitasi anak karena telah merenggut masa kanak-kanak

${ }^{28}$ Idem hlm 175 
mereka sehingga masa kecil mereka digunakan untuk memikirkan hal yang sebenarnya belum saatnya mereka alami.

Tolak ukur permasalahan ini adalah karena perkawinan dengan usia yang relatif muda. Ketika kita berbicara masalah usia sebagai masyarakat Indonesia, hal ini terikat dengan adanya ketetapan yang terdapat dalam undang-undang No 1 tahun 1974 tentang perkawinan pasal 7, perkawinan usia muda pada dasarnya sangat rawan dalam membina rumah tangga sebab kurangnya kedewasaan, kematangan dan kesiapan fisik, baik materi maupun mental dari pasangan suami istri tersebut.

Artinya bahwa HAM memberikan perlindungan dan jaminan atas hak-hak yang dimiliki oleh setiap individu yaitu salah satunya anak, yang dikatakan sebagai kelompok rentan yang tertuang dalam undang-undang HAM yang wajib dilindungi oleh pemerintah, masyarakat dan lainnya yang berperan penting dalam aspek sosial, dalam hal ini stakeholder di atas mampu berperan secara aktif artinya ketika terjadi hal-hal yang tidak diinginkan dalam masyarakat salah satunya yaitu terjadinya perkawinan dibawah umur maka masyarakat harus melaporkan tindakan tersebut kepada institusi yang berwenang menanganinya yaitu komnas perlindungan anak, maka tindakan tersebut bisa dicegah dan melindungi anak yang melakukan perkawinan di usia muda. Hal ini baru diatur apabila laki-laki dewasa yang menikahi anak dibawah umur.

Terkait jika menemukan masalah yang seumuran menikah dalam hal ini melakukan perkawinan di bawah umur, maka kekuatan hukum bagi mereka adalah dispensasi maupun legalitas hukum adat, dari sudut pandang HAM hal ini tidak bisa di protek karena dari segi keluarga dan pemerintah memiliki kekuatan hukum yang jelas maka aspek HAM tidak memiliki wewenang selanjutnya untuk ditindak lanjuti.

Sangaji Jurnal Pemikiran Syariah dan Hukum 


\section{Simpulan}

Perkawinan pada dasarnya menuju sesuatu yang suci dan sakral untuk dilakukan jika perkawinan mengandung mudharat untuk pasangan suami istri tersebut, terkait dengan perkawinan dibawah umur penulis mencoba memberikan sebuah gambaran bahwa bagaimana kedepannya jika perkawinan ini dilakukan, dampak yang terjadi seperti putus sekolah, miss komunikasi, kekerasan dalam rumah tangga, perceraian dan lain sebagainya yang dihadapi, hal ini bisa terjadi karena mental dan pikiran yang belum siap untuk memasuki dan menerima peran sebagai orang dewasa jika dipaksakan untuk terwujud maka dampak yang seperti penulis paparkan diatas akan dialami.

Peran dari keluarga yaitu orang tua harus lebih menjaga dan melakukan usaha preventif agar pergaulan anak bisa terjaga dan juga orang tua harus mampu membimbing dan tidak mengambil jalan untuk melegalkan keinginan dengan berdalih pada legalitas dispensasi nikah.Kembalikan posisi anak pada tempat dan tugasnya, anak yang dikatakan sebagai aset bangsa dan Negara, anak adalah penerus keluarga yang berharga. Sulit bagi anak untuk melanjutkan sekolah jika sudah menikah maupun bercerai, mereka akan lebih memilih untuk mempertahankan hidup dengan mencari nafkah untuk keluarganya.

Aturan yang diciptakan oleh pemerintah juga harus lebih ketat dan seiring artinya disatu sisi undang-undang tentang HAM begitu melindungi Hak anak,dijamin dan diayomi dan disisi lain justru menimbulkan celah bagi pelaku perkawinan dibawah umur baik dari segi hukum positif maupun hukum adat yang berlaku, mengembalikan marwah hukum yang mampu memberikan manfaat bagi masyarakat adalah suatu keharusan, segala aturan dari produk hukum yang dibuat harus saling berkaitan dengan begitu ketika semuanya balance maka anak sebagai generasi bangsa dan Negara bisa terwujud. 


\section{Daftar Pustaka}

\section{Buku}

Amiruddin. 2014. Penyelesaian Kasus KDRT di Pengadilan Agama. Bandung: CV. Mandar Maju

Anshary, M. 2010. Hukum Perkawinan di Indonesia (Masalahmasalah Krusial). Yogyakarta: Pustaka Pelajar

Erwin, Muhammad. 2013.Pendidikan Kewarganegaraan republic Indonesia. Bandung : PT refika aditama

Gultom, Maidin. 2013. Perlindungan Hukum terhadap Anak dan Perempuan.Bandung: PT. Refika Aditama

Hadikusuma, Hilman. 2007. Hukum Perkawinan Indonesia (Menurut Perundangan, Hukum Adat, Hukum Agama).Bandung: : CV. Mandar Maju

Hanif, Yusuf. 2011. Kontroversi Perkawinan Anak dibawah Umur (Child Marriage).Bandung: CV. Mandar Maju

John Ran Bartolomev, 2000.Alif Lam Mim Kearifan Masyarakat Sasak.Terj Imron Rosyidi. Yogyakarta : Tiara Wacana.

Kaelan.2010.Pendidikan Pancasila. Yogyakarta : Paradigma

Khaeron Sirin.2009. Fikih Perkawinan dibawah Umur. Jakarta:

Ghalia Indonesia

Kumalasari, Intan dan Andhyantoro, Iwan.2012. Kesehatan

Reproduksi untuk Mahasiswa Kebidanan dan Keperawatan.Jakarta: Salemba Medika.

Lawrence M. Friedman.1967. Legal Theory, (New York: Columbia University)

M. Ali Harakan. 2012. Sirah Nabawiyah. Jakarta : Pustaka AlKautsar

Mohammad, M. Dlori. (2005) Jeratan nikah dini, wabah pergaulan. Yogjakarta: Binar Press.

Nukman, 2009.Yang dimaksud dengan pernikahan dini. Yogyakarta :Paradigma

Rato, Dominikus. 2011.Hukum Perkawinan dan Waris adat 
(Sistem Kekerabatan, Bentuk Perkawinan dan Pola Pewarisan Adat di Indonesia).Surabaya: Laksbang Yustitia.

Sudarsono.2010. Hukum Perkawinan Nasional.Jakarta : Rineka Cipta

Sulkhad, Kaharuddin. 2013. Merarik pada Masyarakat Sasak. Yogyakarta: Ombak.

Syahuri, Taufiqurrohman. 2013. Legislasi Hukum Perkawinan Indonesia :Pro Kontra Pembentukannya Hingga Putusan Mahkamah Konstitusi. Jakarta: Kencana Pernada Media Group.

Wiliam. J. Goode. 1985. Sosiologi Hukum. Alih bahasa Hanoun Hasyim.Jakarta : Diaksara.

Yasin, Nur. 2008. Hukum Perkawinan Islam Sasak.Yogyakarta: UIN-Malang Press

\section{Jurnal}

Maspupah, Ade. 2014. People's Perseption About Early Marriage (A Case Study In Desa Sungai Kuning Kecamatan Singingi Kabupaten Kuantan Singingi). Jom FISIP Volume $1 \mathrm{No}(2), 1$ - 15.

Purba, Rehngena. 2006. Hukum Adat dalam Yurisprudensi, Majalah Hukum Nasional No. 2. ISSN 0216 - 0227, BPHN, Departemen Hukum dan HAM RI.

\section{Perundang-undangan}

Kitab Undang-Undang Dasar 1945.2017 Jakarta: Majelis Permusyawaratan Rakyat

KUHPer (Kitab Undang-undang Hukum Perdata), KUHP (Kitab Undang-undang Hukum Pidana), KUHAP (Kitab Undang-undang Hukum Acara Pidana). 2008. Yogyakarta : Pustaka Yustisia.

Undang-undang Republik Indonesia Nomor 1 tahun 1974 
tentang Perkawinan dan Kompilasi Hukum Islam. 2014. Jakarta: Grahamedia Press.

Undang-undang Nomor 39 Tahun 1999 Tentang Hak Asasi Manusia

Undang-undang Nomor 23 Tahun 2002 Tentang Perlindungan Perempuan dan Anak

www.detikntb.com 